IRA-International Journal of Technology \& Engineering

ISSN 2455-4480; Vol.05, Issue 03 (2016)

Pg. no. $45-55$

Institute of Research Advances

http://research-advances.org/index.php/IRAJTE

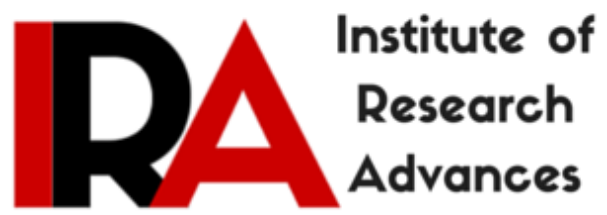

\title{
Effect of Radio Frequency from Cellular System on Human Body \& Its Potential Remedy Li-Fi for Next Generation Wireless Network
}

\section{Pragati Sharma ${ }^{1}$}

Research Scholar, Electronics and Communication Engg., Mewar University, Rajasthan,312901, India.

\section{Dr. A. K. Gautam ${ }^{2}$}

Department of Electronics and Communication Engg.,

S D College of Engineering \& Technology,

Muzaffarnagar 251001 (UP), India.

Type of Reviewed: Peer Reviewed.

DOI: http://dx.doi.org/10.21013/jte.v5.n3.p1

\section{How to cite this paper:}

Sharma, P., \& Gautam, A. (2016). Effect of Radio Frequency from Cellular System on Human Body \& Its Potential Remedy Li-Fi for Next Generation Wireless Network. IRAInternational Journal of Technology \& Engineering (ISSN 2455-4480), 5(3), 45-55. doi:http://dx.doi.org/10.21013/jte.v5.n3.p1

(C) Institute of Research Advances

\section{(cc) BY-NO}

This work is licensed under a Creative Commons Attribution-Non Commercial 4.0 International License subject to proper citation to the publication source of the work.

Disclaimer: The scholarly papers as reviewed and published by the Institute of Research Advances (IRA) are the views and opinions of their respective authors and are not the views or opinions of the IRA. The IRA disclaims of any harm or loss caused due to the published content to any party. 


\begin{abstract}
There is a huge body of evidence in the literature that exposure to radio frequency $(R F)$ has been linked to a variety of adverse health outcomes that may have significant health problems for user of mobile phone. Credible scientific evidences are there that $R F$ radiation from cellular system is responsible to create effect that may be either short term (sleep disruption, lack of concentration, behavioral changes etc) or long term (DNA damage, altered immune function, miscarriage risks, etc.). Cellular region of frequency spectrum covers a vital range of frequency worldwide. It uses Base Transceiver Stations (BTS) and Mobile Station (MS) for its operation therefore the emission of energy from BTS and MS is quite dangerous and needs everyone attention. In second generation systems, BTS works on frequency reuse concept and after few kilometers, we found another BTS to serve the mobile phone. BTS power gets reduced as the distance from BTS to MS increases. At such condition, mobile starts to emit more power to maintain the link and sometimes switches to another nearby BTS area. A new emerging technology, Light- Fidelity ( $\mathrm{Li}$-Fi) is in consideration for future use of communication because it is capable to work safe against health hazards. It can be understood as a carrier to transmit data wirelessly in spite of using radio waves.

In this paper, we tried to check the effects of radio frequency at various conditions. These conditions are studied carefully and a comparative analysis is done (based on available literature) to aware mankind regarding harmful effects of radiation from cellular system on human body and also focus on its proposed remedy to overcome the hazardous effects of electromagnetic radiation.
\end{abstract}

Keywords: Radio frequency (RF), Cell phone, Specific absorption rate (SAR), Electromagnetic wave (EM wave), Human body, Base Transceiver Station (BTS), Global system for mobile communication (GSM), Light Fidelity (Li-Fi), Technology, Entertainment and Design (TED), Light Emitting Diode (LED)

\title{
Introduction
}

In the era of digitization, the mobile communication is considered as the fundamental need of daily life yet it is also considered as potential health risks prone by researchers, government and other concerning institutions. Mobile phones are considered as low powered radio frequency radiation emitting device. This radiated output power may vary from one cell phone to other cell phone. Cell phone can operate continuously or sporadically therefore total exposure of electromagnetic field (EMF) radiation is quite variable.

With the advancement in frequency, we are now exposed to increasing number of EMFs, including extra low frequency EMFs from electric power lines to EMF from cell phones, microwaves and other devices working $\mathrm{n}$ radio region of frequency. International guidelines on exposure level to radio frequency such as ICNIRP $^{1}$, IEEE $^{2}, \mathrm{FCC}^{3}$ etc limits the power level of wireless devices considering body parameters and health effects. Interaction of radio frequency with a human is a multidimensional issue which depends on many parameters like distance of tower, frequency of EM wave, conductivity of mass, density of body etc. The power level of the cell phone increases or decreases automatically within a certain span to accommodate for different situations such as inside or outside of building thus total radiation is a changeable factor for human being.

The WHO in 2011, classifies radio-frequency electromagnetic radiation (that is emitted by Wi-Fi routers and cell phones) as "possibly carcinogenic to humans" due to its radiation effect on body ${ }^{4}$. The rate at which electromagnetic radiation is absorbed by the human body is calculated by specific absorption rate (SAR). Its value decreases as the source of radiation (i.e. cell phone) is kept away from body but for close distance it is very harmful ${ }^{5}$. In case, SAR value calculated is found beyond the critical level i.e. set by various international organizations working in this regard then the continuous radiation may create 
several health problems. Radiation occurs due to electromagnetic field of radio frequency waves (RF waves) and it can be overcome using the upcoming technology Li-Fi.

$\mathrm{Li}-\mathrm{Fi}$ is light fidelity and same as Wi-Fi, the only difference is that Wi-Fi uses RF waves while Li-Fi uses light waves for data transfer thus we may get rid of the radiation effects that was due to radio frequency electromagnetic field. The originator of this fabulous idea was Harald Haas from University of Edinburgh, UK in his TED Global talk on Visible Light Communication. Li-Fi is a highly intelligent system over $\mathrm{Wi}-\mathrm{Fi}$ which is able to transmit a very high bit rate data with minimum interference ${ }^{6}$. To transmit the digital signal through $\mathrm{Li}-\mathrm{Fi}$, signal is encoded as ' 1 ' for light and ' 0 ' for no light conditions. This communication comes under visible light communication (VLC) class which uses pulses of light to transmit data at such a high speed that cannot be detected by human eye. The prime point of consideration is that visible light is not injurious to vision or health as it was the case of RF waves and it offers a wide spectrum to use than that of RF spectrum (approximately 10,000 times wide) shown in Fig-1.

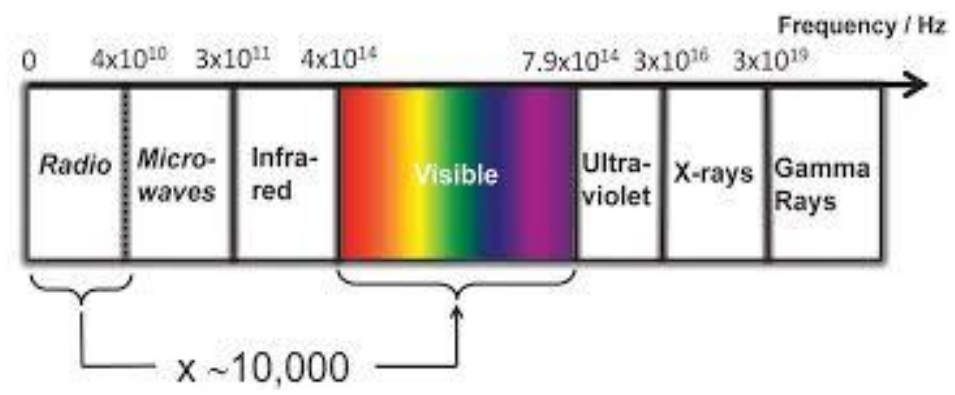

Fig-1: Visible Light Spectrum

The next generation wireless network may face lot of security risks due to using existing radio waves e.g. VoIP threats, dropping of private conversation, end-user equipments may become a source of malicious attacks worms, viruses, calls and spam mails and so on. All these unsecureness of next generation wireless communication can be avoided by changing the RF wave with light waves. ${ }^{7}$

\section{Materials \& Methods}

There is a main task to evaluate and assess the articles and the scientific weight that is to be given to each of them. Only those studies which are found relevant for the task are cited in the reference list while many more are studied. Focus is given on last ten years articles.

There are many categories to study the effects of radio frequency from cellular system on human body. The categories which are studied in this paper are-

Study-1: Whether the use of hands free will decrease the radiation effect

Study-2: Whether the time limit of exposure on human body concerns with the absorption rate

Study-3: Whether the use of Bluetooth, Wi-Fi etc. is linked with any health issue

Study-4: Whether keeping the mobile phone away from body will decrease the radiation

Study-5: Whether the age factor of cell phone user (child, adult, old) is a matter of concern

Study-6: Whether specific absorption rate (SAR) is consult with the frequency of EM wave

Study-7: Whether the distance of RF tower vs. Human is a matter of concern

A health risk assessment evaluates the evidence within each of these categories and then weights together the evidence across the categories to form a combined assessment. 


\section{EMF generation}

The cellular systems are high capacity land mobile system in which assigned radio spectrum is divided into discrete channels which are assigned in groups of geographic cells covering cellular geographic area. A small geographic region which is served by a single base transceiver station (BTS) for communication is known as cell. The discrete channels are capable of being reused in different cells through a process known as frequency reuse ${ }^{8}$.

Each user is defined by its own geographical area which is governed by BTS. BTS can communicate to other BTS through mobile switching centre (MSC) as shown in Fig-2(a).If a user is moving from one BTS to other BTS then the chances of radiation gets increase because induced EMF is high at boundary of cell.BTS communicate through MS using radio waves as a source of EMF generation in its geographical area shown in Fig-2(b).Here 1-7 are depicting the BTS of concerned cell and forming one cluster which may repeat its frequency in nearby cluster.

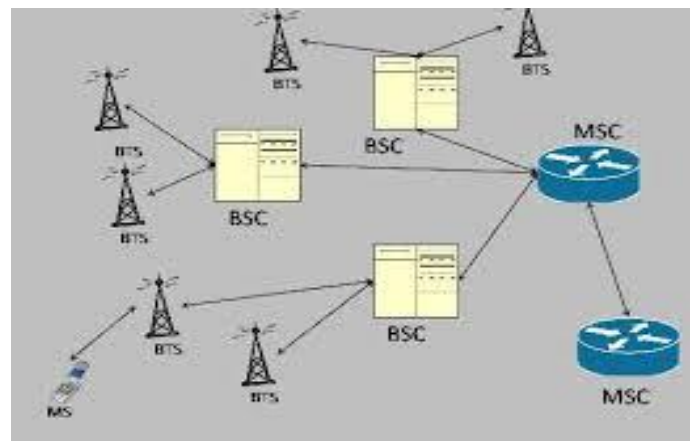

(a): Basic cellular structure diagram

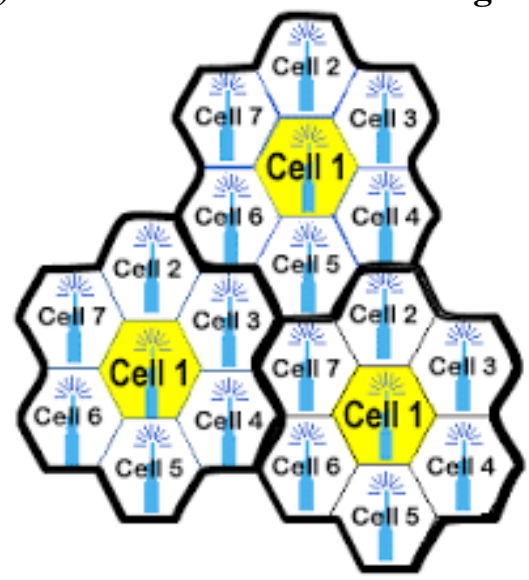

(b) Geographical cells and frequency reuse concept Figure-2

\section{SAR}

SAR stands for 'Specific Absorption Rate' which is basically the amount of radiation a human body will absorb from any source of EM energy that may be a base transceiver station or a cell phone. Thus SAR depicts the rate at which the electromagnetic energy is converted into heat ${ }^{9}$. The higher the rate, the high radiation will be absorbed. The standard limit of SAR set for cell phone radiation for the public is 1.6 Watt/Kg averaged over one gram of body tissue.

SAR is considered as "absorbed dose rate" and is calculated through electric field measurements at a point by-

$\mathrm{SAR}=\sigma \mathrm{E}_{\mathrm{i}}^{2} \rho \rho \quad \mathrm{Watt} / \mathrm{Kg}$ 
Where $\sigma=$ electric conductivity of the tissue $(\mathrm{S} / \mathrm{m})$

$\rho=$ mass density of the tissue $\left(\mathrm{Kg} / \mathrm{m}^{3}\right)$

$\mathrm{E}_{\mathrm{i}}=\mathrm{rms}$ electric field strength inside the tissue

$(\mathrm{V} / \mathrm{m})$

\section{Li-Fi}

It uses an array of Light emitting diodes (LED) which transmits data by varying light intensity ${ }^{10}$. The requirement is a controller that code data into those LEDs. The whole transmission and data encoding can be controlled by varying the LED flickering rate ${ }^{11}$.

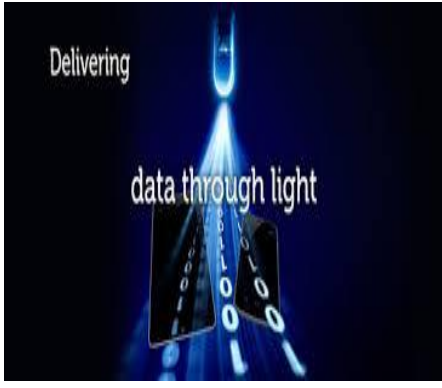

(a)Data transmission in $\mathbf{L i}-\mathrm{Fi}$

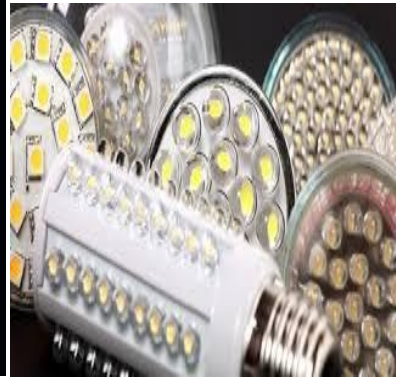

(b)Li-Fi tubes

Figure-3

It is possible to encode data in the Light by varying the rate at which the LEDs flicker on and off to give different strings of $1 \mathrm{~s}$ and $0 \mathrm{~s}$. The LED intensity is modulated so rapidly that human eye cannot notice, so the output appears constant. Devices which are used for

reception purpose in visible light communication are pin photodiode, Avalanche photo diode and Image sensor. Table -1 shows Li-Fi vs. Wi-Fi in a glance.

Table-1: Wi-Fi vs. Li-Fi

\begin{tabular}{|l|l|}
\hline Li-Fi & Wi-Fi \\
\hline Light used as carrier wave & Radio waves used as carrier \\
\hline $\begin{array}{l}\text { Data transfer speed is very high }\left(10 \times 10^{9}\right. \\
\text { bits per second) }\end{array}$ & $\begin{array}{l}\text { Data transfer speed is low } \\
\text { comparatively Li-Fi (150 x10 bits } \\
\text { per second })\end{array}$ \\
\hline $\begin{array}{l}\text { Visible light spectrum has 10,000 times } \\
\text { broad spectrum than RF waves. }\end{array}$ & $\begin{array}{l}\text { RF spectrum has less range than } \\
\text { visible light spectrum }\end{array}$ \\
\hline $\begin{array}{l}\text { Its operating frequency is in Hundreds of } \\
\left.\text { THz (1 THz }=10^{12} \mathrm{~Hz}\right)\end{array}$ & $\begin{array}{l}\text { operating frequency is } 2.4 \mathrm{GHz} \quad(1 \\
\left.\mathrm{GHz}=10^{6} \mathrm{~Hz}\right)\end{array}$ \\
\hline Cheaper in cost & Expensive \\
\hline $\begin{array}{l}\text { No monthly bill/recharge because here we } \\
\text { will using light waves for data transfer }\end{array}$ & $\begin{array}{l}\text { Bill Occurs due to using RF } \\
\text { spectrum }\end{array}$ \\
\hline
\end{tabular}




\section{Results and Discussions}

Seven categories discussed earlier in materials and methods are checked against literature shown in Table-2 and the fact found is that cell phone is hazardous to user at critical conditions. It may be a close distance with user or high time use of cell phone or some child specific effects. The radiation from electromagnetic waves is measured by specific absorption rate in Watt/Kg. Specific absorption rate (SAR) is being calculated and checked for safety level against the maximum SAR value of $1.6 \mathrm{Watt} / \mathrm{Kg}$ decided by many national and international agencies like International Commission Of Non Ionizing Radiation Protection (ICNIRP), National council on Radiation Protection and measurement (NCRP), World Health Organization (WHO), and Federal Communication Commission (FCC). Above this critical value of SAR, cell phone use becomes hazardous for human body.

Table-2: Effect of Electromagnetic Radiation at Various Conditions

\begin{tabular}{|c|c|c|}
\hline STUDY TITLE & \begin{tabular}{l|} 
REVIEWED \\
LITERATURE
\end{tabular} & ANALYSIS DISCUSSED IN PAPER \\
\hline $\begin{array}{l}\text { STUDY-1 } \\
\text { Whether the use of } \\
\text { hands free will decrease } \\
\text { the radiation effect }\end{array}$ & Ref-12 & $\begin{array}{l}\text { To reduce exposure to RF energy, use a hands free option, } \\
\text { such as the built-in speaker phone, the supplied headphones or } \\
\text { other similar accessories. }\end{array}$ \\
\hline $\begin{array}{l}\text { STUDY-2 } \\
\text { Whether the time limit } \\
\text { of exposure on human } \\
\text { body concerns with the } \\
\text { absorption rate }\end{array}$ & $\begin{array}{l}\text { Ref-12 } \\
\text { Ref-13 } \\
\text { Ref-14 }\end{array}$ & $\begin{array}{l}\text { Brain tumor risk is significantly elevated for those who have } \\
\text { used mobile phones for at least a decade. } \\
\text { Analysis shows an almost doubling of the risk of head tumors } \\
\text { induced by long term mobile phone use or latency. } \\
\mathrm{E}_{\text {max }} \text { values exceeded } 2.2 \text { times the } \mathrm{E}_{\text {weighted }} \text { values in the TCH } \\
\text { channels, this is not the case for the BCCH channel, where } \\
\text { the two parameters are mostly the same. While during low- } \\
\text { traffic hours, the ratio between } \mathrm{E}_{\text {weighted }} / \mathrm{E}_{\text {max }} \text { is generally } \\
\text { around } 60 \% \text {, during high traffic hours this becomes around } \\
80 \% \text {. However, the actual exposure is given by } \mathrm{E}_{\text {weighted values. }} \\
\text { In summary there is a reasonable basis to conclude that RF- } \\
\text { EMFs are bioactive and have a potential to cause health } \\
\text { impacts. There is a consistent pattern of increased risk for } \\
\text { glioma and acoustic neuromas associated with heavy use of } \\
\text { wireless phones (mobile phone and cordless phones) mainly } \\
\text { based on results from case control studies from the Hardell } \\
\text { group and Interphone final study results. Epidemiological } \\
\text { evidence gives that RF-EMF should be classified as a human } \\
\text { carcinogen. }\end{array}$ \\
\hline
\end{tabular}




\begin{tabular}{|c|c|c|}
\hline $\begin{array}{l}\text { STUDY-3 } \\
\text { Whether the use of } \\
\text { Bluetooth, Wi-Fi etc. is } \\
\text { linked with any health } \\
\text { issue }\end{array}$ & Ref-16 & $\begin{array}{l}\text { WiFi has a carrier signal in the } 2.4 \mathrm{GHz} \text { range (which is nearly } \\
\mathrm{SHF} \text { ) for } 802.11 \mathrm{~b} / \mathrm{g} / \mathrm{n} \text { standard and at } 5 \mathrm{GHz} \text { range at } 802.11 \mathrm{a} \\
\text { with some more recent devices operating in the } 56 \mathrm{GHz} \text { range. } \\
\mathrm{WiFi} \text { radiation is commonly termed } \mathrm{RF} \text { (radio frequency) } \\
\text { radiation because it operates within the range } 3 \mathrm{kHz}-300 \mathrm{GHz} \text {. } \\
\text { It is also called microwave radiation. For me the biggest } \\
\text { problem with WiFi is that these things throw out } \\
\text { electromagnetic radiation } 24 / 7 \text {. And it's pulsed microwave } \\
\text { radiation just like cell phones. } \\
\text { Paper states that more use of Wi-Fi decreases human sperm } \\
\text { motility and harmful for body. }\end{array}$ \\
\hline $\begin{array}{l}\text { STUDY-4 } \\
\text { Whether keeping the } \\
\text { mobile phone away } \\
\text { from body will decrease } \\
\text { the radiation }\end{array}$ & Ref-12 & $\begin{array}{l}\text { Carry I Phone at least } 10 \mathrm{~mm} \text { away from your body to ensure } \\
\text { exposure levels remain at or below the as tested levels. Cases } \\
\text { with metal parts may change the RF performance of the } \\
\text { device, including its compliance with RF exposure guidelines, } \\
\text { in a manner that has not been testified or certified. } \\
\text { Don't hold a cell phone directly up to your head. Use a } \\
\text { headset or speakerphone when using the device, or a non- } \\
\text { metal case that has been independently tested to reduce } \\
\text { radiation up to } 90 \% \text {. } \\
\text { As SAR depicts the absorption rate of radiated power } \\
\text { therefore a high value of SAR proved as dangerous for human } \\
\text { eye and closer distance of cell phone may cause for its } \\
\text { damage. } \\
\text { SAR values also raises linearly with an increase in radiated } \\
\text { power from the cell phone and decreases with the increase in } \\
\text { distance of cell phone and user. }\end{array}$ \\
\hline $\begin{array}{l}\text { STUDY-5 } \\
\text { Whether the age factor } \\
\text { of cell phone user(child, } \\
\text { adult, old) is a matter of } \\
\text { concern }\end{array}$ & $\begin{array}{l}\text { Ref-18 } \\
\text { Ref-19 } \\
\text { Ref-20 }\end{array}$ & $\begin{array}{l}\text { Paper shows that studies carried out in Sweden indicate that } \\
\text { those who begin using either cordless or mobile phones } \\
\text { regularly before age } 20 \text { have greater than a fourfold increased } \\
\text { risk of ipsilateral glioma. } \\
\text { The dielectric properties of tissues indicate how easily } \\
\text { material can absorb microwave radiation and determine the } \\
\text { tissue's response to an electromagnetic current. The measured } \\
\text { properties are the conductivity }(\sigma) \text { which is directly } \\
\text { proportional to the SAR, and the permittivity }(\varepsilon) \text {. } \\
\text { Higher resolution computerized models based on real human } \\
\text { imaging data suggest that the higher conductivity and higher } \\
\text { permittivity in children's brain tissues together with their } \\
\text { thinner skulls and smaller heads will lead to higher SARs in } \\
\text { their brains from microwave frequencies when compared to } \\
\text { adults. Thus, Children are at higher risk. } \\
\text { In general, an on average, children suffer a higher exposure of } \\
\text { their brain regions than adults. This higher exposure is due to } \\
\text { differences in anatomical proportions. } \\
\text { Paper states that the risk in children of age less than } 20 \text { years }\end{array}$ \\
\hline
\end{tabular}




\begin{tabular}{|c|c|c|}
\hline & & $\begin{array}{l}\text { is of many more folds increase than the risk in adults. The } \\
\text { chances of parotid gland tumor (a salivary gland in the cheek) } \\
\text { and acoustic neuroma (a tumor on the auditory nerve) have } \\
\text { increased. } \\
\text { There is a large body of evidence that childhood exposure to } \\
\text { environmental agents poses greater risk to health than } \\
\text { comparable exposure during adulthood. There is a reason to } \\
\text { expect that children would be more susceptible to the effects } \\
\text { of EMF exposure since they are growing, their rate of cellular } \\
\text { activity and division is more rapid and they may be more at } \\
\text { risk for DNA damage and subsequent cancers. }\end{array}$ \\
\hline $\begin{array}{l}\text { STUDY-6 } \\
\text { Whether specific } \\
\text { absorption rate (SAR) } \\
\text { is consult with the } \\
\text { frequency of EM wave }\end{array}$ & Ref-18 & $\begin{array}{l}\text { Results depicts that the increase in frequency increases SAR } \\
\text { value. The radiation becomes more harmful and beyond } \\
\text { tolerable limits as the distance from transmission decreases. } \\
\text { EMF of different frequencies interact with the body in } \\
\text { different ways depending on the amount of energy associated } \\
\text { with the electromagnetic waves. Gamma rays and X-rays have } \\
\text { frequencies (and energies) high enough to knock an electron } \\
\text { off its atom and break bonds between molecules. This } \\
\text { phenomenon is called Ionizing radiation. Fields at lower } \\
\text { frequencies produce Non-Ionizing radiation. } \\
\text { Power grids and electrical devices are a source of extremely } \\
\text { low frequency (ELF) fields while wireless devices and BTS } \\
\text { are a source of radio frequency (RF) radiation. These } \\
\text { exposures induce currents within the human body and cause } \\
\text { two types of effects either thermal or non thermal. If strength } \\
\text { of these current is sufficiently large, these currents could cause } \\
\text { stimulation of nerves and muscles or affect other biological } \\
\text { processes. } \\
\text { The intensity of EMF interactions with DNA leads to greater } \\
\text { effects on DNA as the energy increases with frequency. } \\
\text { Lower frequency range: Its frequency lies between } 300 \mathrm{~Hz} \text { to } \\
1 \text { MHz .In this range induction current may damage the } \\
\text { performance of central nervous system. } \\
\text { Intermediate frequency range: Its frequency lies between } 100 \\
\mathrm{kHz} \text { to10 GHz. In this range when EMF is absorbed heat is } \\
\text { generated. } \\
\text { Upper frequency range: Its frequency lies between } 10 \mathrm{GHz} \text { to } \\
300 \mathrm{GHz} \text {. In this range superficial tissues may get heated up. } \\
\text { Biological effects that occur when tissues are heated up due to } \\
\text { Radio frequency radiations are called as thermal effects. }\end{array}$ \\
\hline $\begin{array}{l}\text { STUDY-7 } \\
\text { Whether the distance of } \\
\text { RF tower vs. human is a } \\
\text { matter of concern }\end{array}$ & Ref-24 & $\begin{array}{l}\text { The paper concludes that the radiated power near transmission } \\
\text { tower is very high and its value gets decreases with the } \\
\text { increase in distance. Far field radiation on whole body due to } \\
\text { transmission tower is proved as dangerous for those who are } \\
\text { working near tower up to a distance of } 25 \mathrm{~m} \text { at } 900 \mathrm{MHz} \text { and } \\
30 \mathrm{~m} \text { at } 1800 \mathrm{MHz} \text {. }\end{array}$ \\
\hline
\end{tabular}


On the basis of observation cited in Table-2, It can be pointed that that Radio frequency offers high hazards to human kind. The radiation possessed by radio waves can be overcome if the communication occurs in some different region of frequency. Li-Fi offers a better solution to minimize the effect of radio frequency waves. It consist several advantages over Wi-Fi-

\section{Free from radiation and Higher}

speed

Safely used in planes and under

water communication

Safe from hacking and cost

effective

\section{Conclusion}

In summary, it can be concluded that there are huge evidences for short term and long term effects of electromagnetic fields emitted by mobile phones. These effects can be overcome if we become able to replace all the radio wave into optical waves near the handset then there will be no doubt to say that updating of technology is beneficial to human kind. The mobile phone radiation then can be totally refined. Li-Fi is currently attracting a great deal of interest because it may offer a genuine and very efficient alternative to overcome the radio-based wireless hazards. This may also solve issues such as the shortage of radio-frequency bandwidth Therefore it can be conclude that $\mathrm{Li}$-Fi appears as a future generation technology that will revolutionize the researches in this field.

Apart from this, we recommended following precautions to minimize the adverse health effects on human body for existing cellular structure.-

- Check cell phones SAR rating rated on your cell phone by dialing *\#07\#. It should be less than 0.08 Watt/Kg for whole body exposure and $1.6 \mathrm{watt} / \mathrm{Kg}$ for part of body.

- Keep a safe distance with mobile towers.

- Preferably use the cell phone for short time only. If long call then give break in your call to avoid long term exposure.

- Use safe headsets during the call and try to keep cell phone as distant from the body as one can.

- Avoid cell phone putting in your left pocket as it is closer to heart.

- Keep the cell phone away during sleep hours to sustain uninterrupted sleep.

- If cell phone is directly placed at ear to receive call then try to switch its position between left and right ear to minimize radiation effect.

- Try to keep cell phone out of reach to children as they are more susceptible to cell damage.

- Use landline when there is need of a long call.

- Avoid unwanted calls.

- Avoid calling when the network is weak because then the mobile radiates maximum.

\section{Acknowledgement}

The authors great-fully acknowledge the suggestions and comments of the learned reviewers which finally helped to improve the content of the manuscript. 


\section{References}

1. International Commission on Non-Ionizing Radiation Protection (ICNIRP) Guidelines for limiting exposure to time varying electric, magnetic and electromagnetic fields, 1998, Health Phys (USA), 74(4):494-522.

2. Safety Issues associated with base station used for personal wireless communication, 2001, IEEE, New York,110-114.

3. David L. Means \& Kwok W. Chan, Office of Engineering \& Technology, Federal Communications Commission, Washington, D.C. 20554, 'Evaluating compliance with FCC guidelines for human exposure to radio frequency electromagnetic fields, Supplement C(Edition 01-01)to OET Bulletin 65 (Edition 97-01)

4. "IARC Classifies Radiofrequency Electromagnetic Fields As Possibly Carcinogenic To Humans",2011, World Health Organization(WHO)

5. Pragati Sharma, A K Gautam and Sandeep Kumar,2013 Assessment of electromagnetic radiation for second and third generation frequency spectrum on human body, Indian Journal of Radio \& Space Physics, 42: 425-428.

6. Haas, Harald, 2011,"Wireless data from every light bulb". TED Global. Edinburgh, Scotland.

7. Sumant $\mathrm{Ku}$ Mohapatra, BiswaRanjan Swain and Pravanjan Das,2015, Comprehensive Survey Of Possible Security Issues On $4 \mathrm{~g}$ Networks, International Journal of Network Security \& Its Applications (IJNSA), 7(2)

8. Thedore S. Rappaport,2002 Wireless Communication-Principles \& Practices, Pearson, Second edition

9. Adair E R \& Peterson R C,2002, Biological effects of radio frequency/microwave radiation, IEEE Trans Microwave Theory Technique(USA),50:953.

10. 'Visible-light communication: Tripping the light fantastic: A fast and cheap optical version of Wi-Fi is coming', The Economist, dated 28 Jan 2012.

11. 'Li-Fi: Data through Light', The Institute of Engineers,2012, Technorama Magazine, 62:41.

12. Devra Lee Devis, Santosh Kesari, Colin L. Soskolne, Anthony B. Miller, Yeal Stein,2013, Swedish review strengthens the grounds for concluding that radiation from cellular and cordless phones is a probable human carcinogen, Pathophysiology, 123-129

13. A.G.Levis,N. Minicuci, P.Ricci, V. Gennaro,S. Garbisa, 2011,Mobile Phones \& Head Tumors. The discrepancies in cause-effect relationships in the epidemiological studies-How do they arise?, Environmental Health, 10:59

14. Simona Miclaus, Paul Bechet, Cora Iftode,2013, The application of a channel individualized method for assessing long-term, realistic exposure to radio frequency radiation emitted by mobile communication base station antennas, Measurement 46:1355-1362

15. Lennart Hardell, Michael Carlberg, Kjell Hansson Mild,2013, Use of mobile phones and cordless phones is associated with increased risk for glioma and acoustic neuromas, Pathophysiology, 20:85110

16. Avendano C. et al., 2012. Use of laptop computers connected to internet through WiFi decreases human sperm motility and increases sperm DNA fragmentation. Fertility and Sterility 97(1): 3945

17. Pragati Sharma, A.K.Gautam, Sandeep Kumar,2015, Comparative Assessment Of SAR under different power density exposure for human eye for near field radiation of electromagnetic wave at wireless communication of $900 \mathrm{MHz}$ and $1800 \mathrm{MHz}$ frequency, International Journal Of Advanced networking \& Applications(IJANA), 23-26

18. Blank M, Godman R.,2009 Electromagnetic field stress living cells, Pathophyiology,16:71-78.

19. Christ A, Gosselin M.C., Christopolou M, Kubn S, Kuster N,2010 Age dependent tissue specific exposure of cell phone users, Physics in medicine and biology,55:1767

20. Public health implications on wireless technologies,2009 Institute for health and environment, USA

21. J.Pronczuk-Garbino(Ed.),2005, Children's health and the environment: A Global Perspective, World Health organization, Geneva,Switzerland, 367. 
22. Claudia Rada, Susan Perry,2014,Mobile phone infrastructure regulation in Europe: Scientific challenges and human rights protection, Environmental science and policy,37:204-214

23. Pragya Singh, 2013, Wireless Radiation: A Threat To Human Health, International Journal of Technical Research and Applications, 1(2) : 13-19

24. Pragati Sharma, A.K.Gautam, Sandeep Kumar,2014, Comparative SAR assessment for GSM at 900 $\mathrm{MHz}$ and $1800 \mathrm{MHz}$ for whole body exposed under BTS, International Journal of Advanced in Communication Engineering, IJACE, 6(1):101-106. 